Самсонова Вікторія Володимирівна кандидат економічних наук, старший науковий співробітник, доцент кафедри туристичного та готельно-ресторанного бізнесу i консалтингу, Національний університет біоресурсів i природокористування України, вул. Героїв Оборони, 15, м. Київ, 03041, тел.: (044) 527-81-54, e-mail: samsonova_v@ @ubip.edu.ua, https://orcid.org/0000-0003-25652497

\title{
МІСЦЕ І РОЛЬ ПРОФЕСІЙНОЇ ЕТИКИ У ТРАНСФОРМАЦІЇ СИСТЕМИ ЦІННОСТЕЙ ДЕРЖАВНОГО СЛУЖБОВЦЯ
}

Анотація. У статті проведено дослідження ролі професійної етики у трансформації системи цінностей державного службовця. Визначено, що в процесі побудови правової, демократичної, соціальної держави зростає значимість моральної складової діяльності державних службовців, яка стає важливим елементом формування довіри й партнерських відносин між громадою та владою, вагомим важелем запобігання корупції, ресурсом управління професійною діяльністю, чинником стимулювання високого професіоналізму.

3'ясовано, що істотну роль у формуванні етики державної служби зіграли історичні реалії формування державної служби в тій або іншій країні. Вони робили етичні вимоги конкретнішими, обумовленими історичними реаліями цієї країни.

Відмічено, що сучасна професійна етика державного службовця базується на усвідомленні професійного призначення і тісно пов'язана з увагою до проблеми особистісних вимірів як індивіда, так і професіонала. Моральні цінності особистості допомагають державним службовцям зорієнтуватись в тому, яку поведінку на службі слід вважати припустимою, а яку ні. У процесі ж професійної діяльності виникають вже специфічні норми взаємодії, ціннісні орієнтації, відносини. Професійна етика фіксує інституційну свідомо сформовану систему професійно-етичних цінностей, принципів i норм, які відображаються $\mathrm{y}$ свідомості державних службовців, орієнтують i регулюють їх відносини, діяльність у сфері державної служби та механізми підтримки професійно-етичної складової державної служби.

Акцентовано увагу, що 3 демократизацією суспільства, 3 появою нових соціальних викликів формується потреба переосмислення цінностей управлінського середовища виходячи 3 пріоритетного статусу людини в соціумі. 
Ціннісно-нормативна модель як на рівні державного управління в цілому, так і на рівні державних службовців має складатись із зосереджених навколо місії професії цінностей, принципів, необхідних для професійної діяльності моральних якостей та норм і стандартів поведінки державних службовців.

Результати дослідження дозволяють стверджувати, що від ціннісних основ державно-управлінської діяльності, етичної обгрунтованості прийняття професійних рішень, моральних якостей та цінностей державних службовців, рівня їх етичної культури залежить ступінь довіри до владних структур, націленість діяльності органів державної управління на побудову демократичної держави, реалізацію принципів прозорості, дотримання прав людини та соціальної справедливості.

Ключові слова: державний службовець, мораль, професійна етика, цінності, етична поведінка, етичний кодекс.

Samsonova Viktoriia Vladimirovna $\mathrm{PhD}$ (Economics), Senior Researcher, Associate Professor of Tourism and Hotel and Restaurant Business and Consulting, National University of Life and Environmental Sciences of Ukraine, Heroiv Oborony St., 15, Kyiv, 03041, tel.: (044) 527-81-54, e-mail: samsonova_v@nubip.edu.ua, https://orcid.org/0000-0003-2565-2497

\section{THE PLACE AND ROLE OF PROFESSIONAL ETHICS IN THE TRANSFORMATION OF THE CIVIL SERVANTS 'VALUE SYSTEM}

Abstract. Study of the role of professional ethics in the transformation of the value system of civil servants was conducted in the article. It is determined that in the process of building a legal, democratic, social state, the importance of the moral component of the activities of civil servants increases. This becomes an important element of building trust and partnership between the community and the government, a significant lever in preventing corruption, a resource for managing professional activities, a factor in stimulating high professionalism.

It was found that the historical realities of the formation of the civil service in a country played a significant role in shaping the ethics of the civil service. They made ethical requirements more specific, due to the historical realities of this country.

It is noted that the modern professional ethics of a civil servant is based on the awareness of professional purpose and is closely related to the attention to the problem of personal dimensions of both the individual and the professional. Moral values of the individual help civil servants to orient themselves in what behavior in the service should be considered acceptable and what should not. In the process of professional activity there are already specific norms of interaction, value orientations and relations. 
Professional ethics captures the institutional consciously formed system of professional and ethical values, principles and norms that are reflected in the minds of civil servants guide and regulate their relations, activities in the civil service and mechanisms to support the professional and ethical component of civil service.

Emphasis is placed on the fact that with the democratization of society, with the emergence of new social challenges, there is a need to rethink the values of the management environment based on the priority status of man in society. The valuenormative model both at the level of public administration as a whole and at the level of civil servants should consist of the values, principles necessary for professional activity of moral qualities and norms and standards of behavior of civil servants centered on the mission of the profession.

The results of the study suggest that the degree of trust in government depends on the values of public administration, ethical validity of professional decisions, moral qualities and values of civil servants, the level of their ethical culture, the focus of public administration on building a democratic state, implementing the principles of transparency, respect for human rights and social justice.

Keywords: civil servant, morality, professional ethics, values, ethical behavior, code of ethics

Постановка проблеми. Визначення ролі професійної етики державного службовця у формуванні його системи цінностей $\epsilon$ актуальною проблемою наукових пошуків багатьох дослідників, оскільки постійно виникає потреба у вивченні системи складових професійної етики, як одного 3 найважливіших чинників, що впливають на ефективність роботи державної служби.

Ціннісні орієнтації, які формує професійна етика у державного службовця, базуються на ціннісній системі суспільства та кардинально впливають на становлення, функціонування та розвиток держави та іï інститутів. Відомим $є$ факт, що суспільна довіра до державних службовців є фундаментальною умовою ефективного державного управління, а моральні стандарти поведінки державних службовців стають основоположним фактором, що саме і визначає якість та ефективність державного управління.

Державна політика буде підтримуватися й позитивно сприйматися лише в тому випадку, коли цінності, закладені в ії основу, збігаються із суспільними та індивідуальними цінностями дійових осіб і цільових груп політики [1]. У зв'язку з цим, аналіз проблем, що стосуються впливу професійної етики на формування системи цінностей державних службовців видається вкрай актуальним.

Аналіз останніх досліджень і публікацій. Теоретичні аспекти дослідження проблем професійної етики державного службовця та результати аналізу етичних основ державної служби представлені у роботах зарубіжних науковців 
Дж. Боумена, С. Гілмана, Г. Колбеча, Т. Купера, С. Л’юіса, Дж. Перрі, Дж. Планта, Дж. Рора, Дж. Свари та ін. й провідних вітчизняних вчених Т. Е. Василевської, В. М. Князєва, Г. Б. Марушевського, М. І. Рудакевич, В. О. Саламатова та ін. Проблемам формування системи цінностей державної політики присвячені праці В. Парсонса, Д. Істона, Х. Леунг, Д. Стоун та ін. Проте, на нашу думку, не до кінця розробленими є засади визначення, формування й поділяння цінностей державними службовцями в процесі організації професійної діяльності.

Мета статті - виявити місце і роль професійної етики у трансформації системи цінностей державного службовця.

Виклад основного матеріалу. Виділення особливих професійно-етичних настанов, в яких загальнолюдські принципи моралі конкретизуються відносно тієї чи іншої спеціалізованої діяльності, зумовлено низкою факторів:

- своєрідністю місця та діяльності представників професії, сфери діяльності в суспільстві;

- специфікою відносин, що складаються в процесі цієї діяльності;

- підвищеними моральними вимогами, особливою напруженістю, складністю реалізації етичних норм у певних професіях, сферах діяльності [2]. Названі умови мають визначальне значення і для діяльності осіб, уповноважених на виконання функцій держави або місцевого самоврядування. Так:

- державні управлінці займають специфічне місце в суспільстві, вони реалізують державну управлінську діяльність і державно-владні повноваження;

- $\quad$ у професійній діяльності державних управлінців складаються особливі відносини 3 громадянами, які в умовах демократії вибудовуються на засадах служіння представників державного апарату народові, інтересам громадян. Для побудови відносин усередині професійної групи державних службовців кардинальне значення має принцип ієрархії;

- підвищені моральні вимоги в державному управлінні зумовлені: розпорядженням значними матеріальними цінностями, людськими ресурсами; безпосереднім впливом на життя конкретних людей; існуванням ризику, непередбаченості в діяльності, поєднанням формально-процедурних регламентацій діяльності з можливістю прийняття вольових суб'єктивних рішень, імовірним творчим характером праці [3].

Ці чинники призводять до виникнення особливих етичних дилем у діяльності та відносинах державних управлінців (дотримання державної таємниці, протидії корупційним діянням, збереження конфіденційної інформації громадян, політичної неупередженості державних службовців, обмеження частини політичних, природних прав державних управлінців тощо).

Подолання вище зазначених дилем на засадах дотримання принципів 
моральності вимагає від державного службовця усвідомлення та поділяння системи етичних цінностей, дотримання принципів і норм професійної етики.

Дослідники відзначають, що цінності у сфері державного управління:

- $\quad \epsilon$ формою морально-етичної орієнтації та мотивації людей;

- визначають межі альтернатив державного розвитку в контексті співвідношення цілей та засобів, тим самим виступаючи фундаментом конституційно-правового регулювання;

- зумовлюють можливості формування тієї чи іншої комунікації між елітарними та неелітарними прошарками, i як наслідок, внутрішньої інтеграції/дезінтеграції держави та суспільства;

- здатні справляти соціалізуючий вплив на різні прошарки населення та бути основою й каналом передачі досвіду у сфері державного регулювання, оскільки втілюються в традиціях та звичаях суспільства, стереотипах та стандартах управлінської діяльності;

- виступають інструментом організації професійної діяльності в критичних, форс-мажорних умовах завдяки своїй орієнтуючій, позаситуаційній природі [2].

Професійна етика державних службовців та посадових осіб місцевого самоврядування являє собою сукупність моральних правил поведінки, за допомогою яких можна оцінити їх діяльність 3 точки зору таких цінностей, як справедливість, доброчесність, сумлінність, гідність, лояльність, толерантність, відповідальність, професіоналізм тощо. Професійна етика даної категорії посадових осіб грунтується на усвідомленні професійного призначення системи етичних цінностей, принципів і норм, які відображаються у свідомості державних службовців, орієнтують і регулюють їх відносини, діяльність у сфері державного управління.

Етична поведінка державних службовців та посадових осіб місцевого самоврядування грунтується на принципах державної служби та служби в органах місцевого самоврядування, визначених Законами України «Про державну службу» і «Про службу в органах місцевого самоврядування», а також загальних вимогах до поведінки цих осіб, визначених Законом України «Про запобігання корупції», а до 2015 р. - Законом України «Про правила етичної поведінки».

Закон України «Про державну службу» визначає такі принципи роботи державної служби: верховенства права; законності; професіоналізму; патріотизму; доброчесності; ефективності; забезпечення рівного доступу до державної служби; політичної неупередженості; прозорості; стабільності [4].

Закон України «Про правила етичної поведінки» визначав керівні норми поведінки осіб, уповноважених на виконання функцій держави або місцевого самоврядування, під час виконання ними службових повноважень та порядок притягнення їх до відповідальності за порушення таких норм [5]. До основних 
правил етичної поведінки відносились: законність; пріоритет інтересів; політична неупередженість; толерантність; об’єктивність; компетентність і ефективність; формування довіри до влади; конфіденційність; утримання від виконання незаконних рішень чи доручень; недопущення конфлікту інтересів; запобігання одержанню неправомірної вигоди або дарунка (пожертви); декларування майна, доходів, витрат і зобов'язань фінансового характеру.

Порушення особами, уповноваженими на виконання функцій держави або місцевого самоврядування, визначених правил етичної поведінки, тягнуло за собою дисциплінарну, адміністративну, кримінальну та матеріальну відповідальність з урахуванням особливостей правового статусу таких осіб, визначених Конституцією і законами України.

Даний Закон України втратив чинність після прийняття Закону України «Про запобігання корупції» [6]. А визначені ним правила етичної поведінки дещо трансформовано та виділено в окремий розділ. Норми Закону України «Про запобігання корупції» також зобов’язують осіб, уповноважених на виконання функцій держави або місцевого самоврядування, під час виконання своїх службових повноважень неухильно дотримуватись вимог закону та загальновизнаних етичних норм поведінки, бути ввічливими у стосунках 3 громадянами, керівниками, колегами і підлеглими.

Постановою Кабінету Міністрів України від 11 лютого 2016 р. № 65 також затверджено Правила етичної поведінки державних службовців, які регулюють моральні засади діяльності державних службовців та полягають у дотриманні принципів етики державної служби [7]. Державні службовці у своїй діяльності керуються принципами етики державної служби, що грунтуються на положеннях Конституції України, законодавства про державну службу та запобігання корупції, а саме: служіння державі і суспільству; гідної поведінки; доброчесності; лояльності; політичної нейтральності; прозорості і підзвітності; сумлінності.

Узагальнення стандартів етичної поведінки державних службовців та посадових осіб місцевого самоврядування, якими вони зобов'язані керуватися під час виконання своїх посадових обов'язків на основі положень Конституції України, законодавства про державну службу, службу в органах місцевого самоврядування, у сфері запобігання корупції i спрямовані на зміцнення авторитету державної служби та служби в органах місцевого самоврядування, репутації державних службовців та посадових осіб місцевого самоврядування, а також на забезпечення інформування громадян про норми поведінки державних службовців та посадових осіб місцевого самоврядування стосовно них, знайшли відображення у Наказі Національного агентства України 3 питань державної служби «Про затвердження Загальних правил етичної поведінки державних службовців та посадових осіб місцевого самоврядування» [8]. 
Формою публічного проголошення правил i стандартів поведінки, яких очікує від службовця колектив, громадяни, суспільство є етичний кодекс. Ним регулюють моральне середовище при виконанні професійних обов'язків, надаючи або обмежуючи можливість ініціативи та забезпечують відкритість і прозорість діяльності державного службовця [9]. Залежно від домінуючих засобів впливу кодекси мають різні назви. Це можуть бути етичні кодекси, кодекси поведінки, кодекси честі, стандарти чи правила етичної поведінки тощо. Проте, хочемо наголосити, що саме етичний кодекс $\epsilon$ комплексом професійно-етичних цінностей, принципів, норм, стандартів поведінки, що приписуються до виконання. В етичних кодексах державних службовців обов'язково фіксуються цінності, задаються орієнтири для етичного самовдосконалення представників державного управління.

Етичний кодекс має заповнювати прогалину між абстрактними приписами законодавства, які $\epsilon$ загальними принципами поведінки, та конкретними рекомендаціями й правилами поведінки в повсякденно виникаючих ситуаціях. Він має зменшувати ступінь невпевненості та давати поради відносно того, куди має звертатись працівник, коли така складна ситуація виникає. Етичний кодекс повинен ще більше передбачати конкретні моделі поведінки державного службовця в ситуації, що може призвести до до порушення моральних норм та корупційних проявів [10].

Нині в Україні роль професійно-етичних кодексів в державному управлінні відіграє Закон України «Про запобігання корупції», а у державної служби «Загальні правила етичної поведінки державних службовців та посадових осіб місцевого самоврядування», затверджені Наказом Національного агентства України з питань державної служби.

Зважаючи на вище проаналізовану нормативну базу, яка визначає етичні засади роботи вітчизняних державних службовців, можемо сказати, що у діючих нормативних актах йдеться мова про принципи роботи державної служби як механізму, в якому людина є лише елементом і має дотримуватись визначених правил етичної поведінки при виконанні службових обов'язків. I жодного слова про цінності конкретних осіб - державних службовців.

Для порівняння - один із небагатьох світових прикладів інституалізації цінностей державних службовців - нормативна база, що визначає діяльність шведських державних установ. Так, у Швеції діє орган 3 питань базових цінностей, що займається їх формуванням, імплементацією на усіх рівнях державних агенцій та формуванням загальної культури, що запобігає появам корупції серед державних службовців - Рада 3 базових цінностей, головним завданням якої $є$ зміцнення та вдосконалення знань державних службовців та формування поваги до базових цінностей державного сектора, якими $\epsilon$ : 
демократія; законність; об'єктивність; свобода думки; повага до прав людини, свободи та гідності; ефективність та слугування.

Деякі подібні цінності були окреслені в керівних нормах поведінки осіб, уповноважених на виконання функцій держави або місцевого самоврядування, визначених Законом України «Про правила етичної поведінки», проте, як вже зазначалося, цей закон втратив чинність 26 квітня 2015 р. у зв’язку з прийняттям Закону України «Про запобігання корупції», проте, цей доволі прогресивний новий закон так і не спромігся поставити людину до центру українського державного всесвіту.

Якщо порівняти базові цінності державного сектора Швеції із вищенаведеними принципами роботи української державної служби, то можемо спостерігати такі відмінності:

- у Швеції йдеться про цінності службовців, тобто конкретних осіб, в українському законі - про принципи роботи служби як механізму, в якому людина є лише гвинтиком;

- серед цінностей шведських державних службовців двічі згадується свобода, тоді як у вітчизняній нормативній базі, що регулює етичний базис діяльності державної служби, вочевидь, замінює патріотизм;

- серед вітчизняних принципів присутнє служіння народові України та територіальній громаді, яке трактується як захист публічних інтересів, тоді як серед цінностей шведських держслужбовців присутнє «служіння» насамперед, інтересам кожного громадянина [11].

Хотілося б ще зазначити, що базові цінності $є$ несумісними 3 корупцією в будь-якій формі. А високий рівень усвідомлення базових цінностей формує професійну культуру, яка бореться із корупцією на робочому місці. Одним словом, вважаємо, що наразі, як ніколи варто спрямувати зусилля на зміцнення та вдосконалення знань державних службовців та формування поваги до базових цінностей державного сектора.

Зважаючи на те, що цінності відображають те, що є важливим, цінується, до базових цінностей демократично орієнтованого державного управління можна віднести життя та гідність людини, повага до неї, справедливість, солідарність тощо. Для державних службовців система цінностей грунтується в першу чергу на національних інтересах. Система національних інтересів також являє собою багато параметричну ціннісну теорію, яка відображає в узагальненому вигляді потреби суспільства та держави, цілі державного управління і, відповідно, критерії оцінки його ефективності.

Національні інтереси охоплюють три взаємопов'язані рівні в системі цінностей державного управління: мегарівень (універсальні цінності); макрорівень (функціонально-операційні цінності); мікрорівень (принципи 
найпоширеніших зразків поведінки). Цінності мега- і макрорівнів безпосередньо відображаються у змісті національних інтересів України і реалізуються через професійну поведінку державних службовців у рамках парадигми ціннісноорієнтованого управління [3].

Таблиия 1

\section{Система цінностей державного управління через призму національних інтересів}

\begin{tabular}{|c|c|c|}
\hline Мегарівень & Макрорівень & Мікрорівень \\
\hline Універсальні цінності & $\begin{array}{c}\text { Функціонально- } \\
\text { операційні цінності }\end{array}$ & $\begin{array}{c}\text { Принципи найпоширеніших зразків } \\
\text { поведінки }\end{array}$ \\
\hline $\begin{array}{l}\text { - повага лідності } \\
\text { гіюдсьої } \\
\text { - свобода } \\
\text { - демократія } \\
\text { - рівність } \\
\text { - верховенство права } \\
\text { - права людини } \\
\text { - духовність } \\
\text { - патріотизм }\end{array}$ & $\begin{array}{l}\text { - законність } \\
\text { - прозорість } \\
\text { відкритість } \\
\text { - підзвітність } \\
\text { - ефективність } \\
\text { - відповідальність }\end{array}$ & $\begin{aligned} & \text { - } \text { єдність інтересів } \\
& \text { - } \text { субсидіарність } \\
& \text { - } \text { пропорційність } \\
& \text { - } \text { згуртованість } \\
& \text { - } \text { адекватність } \\
& \text { - } \text { інновативність } \\
& \text { - } \text { поєднання позитивного } \\
& \text { негативного зворотного зв'язку } \\
& \text { - } \\
& \text { самоуправління }\end{aligned}$ \\
\hline
\end{tabular}

Джерело: складено за [3]

Погоджуємось 3 думкою колективу вчених [2], що принцип служіння народові $\epsilon$ смисловим ядром, навколо якого має вибудовуватися система ціннісних орієнтацій державних управлінців. Домінуючі цінності державної служби залежно від іiі місії представлено у таблиці 2.

Таблиия 2

\section{Система цінностей державного управління залежно від місії державної служби}

\begin{tabular}{|l|l|l|}
\hline \multicolumn{1}{|c|}{$\begin{array}{c}\text { Місія державної } \\
\text { служби }\end{array}$} & \multicolumn{1}{|c|}{ Державна служба як } & Державна служба як надання послуг \\
\hline \multirow{3}{*}{ Домінуючі } & - громадянськість & - орієнтація на користувача \\
цінності & - рівність & - ефективність \\
& - представництво & - змагальність \\
& - відповідальність & - менеджеризм \\
& - нейтральність & - гнучкість \\
& & - iніціативність \\
& & - партнерство \\
\hline
\end{tabular}

Джерело: складено за [2]

У формуванні ціннісно-нормативної моделі особистості державного 
службовця, забезпеченні його доброчесної поведінки вага особистих професійноетичних якостей професіоналів є дуже значною.

Цінності та принципи державного управління конкретизуються на особистісному рівні державного службовця у вимозі дотримуватися певних професійно-етичних норм, які вказують, як мають діяти представники державного управління, щоб їх поведінка відповідала їх суспільно-правовому статусу [12].

Оскільки професійна діяльність державних управлінців налаштована на виконання визначених професійних функцій, вона потребує від державного службовця наявності певних якостей, які необхідні для його продуктивної діяльності. До таких якостей та характеристик морального та професійноетичного аспекту належать бажання приносити користь суспільству, відданість ідеалам демократії, законослухняність, патріотизм, свобода та гідність, політична неупередженість бюрократії, професіоналізм, повага до прав людини, доброзичливість, схильність до взаємодопомоги та співробітництва, толерантність, працелюбність, відповідальність, сумлінне ставлення до своїх обов'язків, непідкупність, принциповість, вимогливість, справедливість, чесність, стриманість, урівноваженість, коректність і ввічливість, скромність в особистому житті, відчуття професійної честі та професійної гідності тощо.

Професіоналізація через професійну етику впливає на ціннісний світ, на установки працівників; через формування особистості професіонала реалізує й більш широкі впливи на моральні цінності суспільства [3].

Однією з важливих професійно-етичних вимог до державного управлінця є вимога відповідального ставлення до професійної діяльності, а саме відповідальність за додержання специфічних професійних норм, що регулюють поведінку державного службовця.

Крім професійної відповідальності, значну роль у професійному житті державного службовця мають відігравати професійна честь - оцінка значущості, зовнішне суспільне визнання дій та здобутків державного службовця, що виявляється в суспільному авторитеті, i професійна гідність - самооцінка державним службовцем своєї професійної діяльності, внутрішня впевненість у власній цінності як професіонала, почуття самоповаги до власних професійних надбань.

Досить вагомою професійно-етичною рисою державного управлінця має бути толерантність, яка має проявлятися саме в процесі служіння інтересам народу, тобто з повагою ставитись до прав, свобод та законних інтересів людей, об'єднань громадян, інших юридичних осіб; не проявляти свавілля або байдужість до їхніх правомірних дій та вимог; сприймати інших людей в їх 
інакшості; визнавати за цими людьми права на самобутнє існування; утримуватись від агресії та мати терпимість до ідей, звичок, норм поведінки, які не подобаються або викликають неприязнь.

Ціннісно-нормативна модель державного службовця має включати в себе й низку професійно-етичних норм, зокрема державні службовці повинні сумлінно, компетентно, результативно і відповідально виконувати свої посадові обов'язки; бути доброзичливими та ввічливими, дотримуватись високої культури спілкування (не допускати підвищеної інтонації, використання нецензурної лексики); запобігати виникненню конфліктів у стосунках; проявляти ініціативу, а також не допускати ухилення від прийняття рішень та відповідальності за свої дії та рішення. Виконувати свої посадові обов'язки чесно і неупереджено, незважаючи на особисті ідеологічні, релігійні або інші погляди, не надавати будьяких переваг та не виявляти прихильність до окремих фізичних чи юридичних осіб, громадських і релігійних організацій.

Виконання покладених на посадову особу професійних функцій у межах професійної діяльності потребує від особи наявності певних якостей. До переліку моральних і професійно-етичних якостей державного службовця варто зарахувати постійне самовдосконалення, яке пов'язується 3 динамічністю процесів у всіх сферах державного управління та суспільного життя країни, а також 3 необхідністю професійного зростання державного службовця як професіонала та фахівця своєї справи. Дотримання та розвиток вищезазначених професійних якостей та цінностей державним службовцем забезпечить довіру суспільства до державної служби та служби в органах місцевого самоврядування.

Висновки. Підсумовуючи викладене, ще раз зазначимо, що подолання етичних дилем професійної діяльності державного службовця має здійснюватись на засадах дотримання принципів моральності і вимагає від нього усвідомлення та поділяння системи етичних цінностей, дотримання принципів і норм професійної етики. У формуванні ціннісно-нормативної моделі особистості державного службовця, забезпеченні його доброчесної поведінки вага особистих професійноетичних якостей професіоналів є дуже значною.

Цінності та принципи державного управління конкретизуються на особистісному рівні державного службовця у вимозі дотримуватися певних професійно-етичних норм, які вказують, як мають діяти представники державного управління, щоб їх поведінка відповідала їх суспільно-правовому статусу, а ціннісно-нормативна модель як на рівні державного управління в цілому, так і на рівні державних службовців має складатись із зосереджених навколо місії професії цінностей, принципів, необхідних для професійної діяльності моральних якостей та норм і стандартів поведінки державних службовців. 


\section{Jimepamypa:}

1. Парсонс В. Публічна політика: вступ до теорії й практики аналізу політики. пер 3 англ. О. Дем’янчука. Київ. 2006. Видавн. дім “Києво-Могилянська академія”. 520 с.

2. Василевська Т.Е. Особистісні виміри етики державного службовця. Монографія. Київ. 2008. НАДУ. 336 с.

3. Василевська Т.Е., Саламатов В.О., Марушевський Г.Б. Етика державного управління. Підручник. Київ. 2015. НАДУ. 204 с.

4. Про державну службу. Закон України від 16 груд. 1993 р. №3723-XII. Відомості Верховної Ради України. 1993, № 52. С. 490.

5. Про правила етичної поведінки. Закон України від 17 трав. 2012 р. № 4722-VI. Офіційний вісник України. 2012. № 45. С. 82.

6. Про запобігання корупції. Закон України від 14 жовтня 2014 року № 1700-VII. Відомості Верховної Ради України. 2014. № 49.

7. Правила етичної поведінки державних службовців, які регулюють моральні засади діяльності державних службовців. Постанова Кабінету Міністрів України від 11 лютого 2016 р. № 65 .

8. Про затвердження Загальних правил етичної поведінки державних службовців та посадових осіб місцевого самоврядування. Наказ Національного агентства України 3 питань державної служби від 05.08.2016 № 158. Зареєстровано в Міністерстві юстиції України 31 серпня 2016 р. за № 1203/29333.

9. Панфілова Т.О. Етика державного управлінця. Методичні рекомендації. Львів. 2011. ЛРІДУ НАДУ. 44 с.

10. Малімон В.І., Шевченко Н.П. Актуалізація етичних кодексів в контексті модернізації системи державного управління. Науково-інформаційний вісник Івано-Франківського університету права імені Короля Данила Галицького. 2015. № 11. С. 79-85.

11. Формування базових цінностей у державних службовців. [Електронний ресурс]. Режим доступу: https://voxukraine.org/uk/formyvannya-bazovyh-tsinnostei-u-derzhavnyhslyzhbovtsiv-ua/

12. Рудакевич М. І. Етика державних службовців. Монографія. Київ. 2003. НАДУ. 360 с.

\section{References:}

1. Parsons, V. (2006). Publichna polityka: vstup do teoriyi y praktyky analizu polityky [Public policy: an introduction to the theory and practice of policy analysis]. Kyiv: Vydavn. dim "KyyevoMohylyans'ka akademiya" [in Ukrainian].

2. Vasylevs'ka, T.E. (2008). Osobystisni vymiry etyky derzhavnoho sluzhbovtsya [Personal dimensions of civil servant ethics]. Kyiv: NADU [in Ukrainian].

3. Vasylevs'ka, T.E., Salamatov, V.O., \& Marushevs'kyy, H.B. (2015) Etyka derzhavnoho upravlinnya [Ethics of public administration]. Kyiv: NADU [in Ukrainian].

4. Zakon Ukrainy Pro derzhavnu sluzhbu : pryiniatyi 16 hrud. 1993 roku №3723-KHII [Law of Ukraine about civil service from December 16 1993, №3723-XII]. Vidomosti Verkhovnoi Rady Ukrainy - Bulletin of Verkhovna Rada of Ukraine, 52, p. 490 [in Ukrainian].

5. Zakon Ukrainy Pro pravyla etychnoyi povedinky : pryiniatyi 17 trav. 2012 roku № 4722-VI [Law of Ukraine about the rules of ethical conduct from May 17 2012, № 4722-VI]. Ofitsiynyy visnyk Ukrayiny - Official Gazette of Ukraine, 45, p. 82 [in Ukrainian].

6. Zakon Ukrainy Pro zapobihannya koruptsiyi : pryiniatyi 14 zhovtnya 2014 roku № 1700-VII 
[Law of Ukraine about prevention of corruption from October 14 2014, № 1700-VII]. Vidomosti Verkhovnoi Rady Ukrainy - Bulletin of Verkhovna Rada of Ukraine, 49, [in Ukrainian].

7. Postanova Kabinetu Ministriv Ukrayiny «Pravyla etychnoyi povedinky derzhavnykh sluzhbovtsiv, yaki rehulyuyut' moral'ni zasady diyal'nosti derzhavnykh sluzhbovtsiv» : pryiniata 11 lyutoho 2016 roku № 65 [Resolution of the Cabinet of Ministers of Ukraine «Rules of ethical conduct of civil servants, which regulate the moral principles of civil servants» from February 11 2016, № 65] [in Ukrainian].

8. Nakaz Natsional'noho ahentstva Ukrayiny z pytan' derzhavnoyi sluzhby «Pro zatverdzhennya Zahal'nykh pravyl etychnoyi povedinky derzhavnykh sluzhbovtsiv ta posadovykh osib mistsevoho samovryaduvannya» : pryiniatyi 05 serpnya 2016 roku № 158 [Order of the National Agency of Ukraine for Civil Service «On approval of the General rules of ethical conduct of civil servants and local government officials» from August 31 2016, № 158]. Zareyestrovano v Ministerstvi yustytsiyi Ukrayiny - Registered with the Ministry of Justice of Ukraine, August 31, 2016, № 1203/29333, [in Ukrainian].

9. Panfilova, T.O. (2011) Etyka derzhavnoho upravlintsya [Ethics of a public official]. L'viv: LRIDU NADU [in Ukrainian].

10. Malimon, V.I., \& Shevchenko, N.P. (2015) Aktualizatsiya etychnykh kodeksiv v konteksti modernizatsiyi systemy derzhavnoho upravlinnya [Actualization of codes of ethics in the context of modernization of the public administration system]. Naukovo-informatsiynyy visnyk IvanoFrankivs'koho universytetu prava imeni Korolya Danyla Halyts'koho - Scientific and Information Bulletin of Ivano-Frankivsk University of Law named after King Danylo Halytsky, 11, 79-85 [in Ukrainian].

11. Formuvannya bazovykh tsinnostey u derzhavnykh sluzhbovtsiv [Formation of basic values in civil servants]. (n.d.). voxukraine.org. Retrieved from https://voxukraine.org/uk/formyvannyabazovyh-tsinnostei-u-derzhavnyh-slyzhbovtsiv-ua/ [in Ukrainian].

12. Rudakevych, M. I. (2003) Etyka derzhavnykh sluzhbovtsiv [Ethics of civil servants]. Kyiv: NADU [in Ukrainian]. 